\title{
Impact of co-payment level increase of antidiabetic medications on glycaemic control: an interrupted time-series study among Finnish patients with type 2 diabetes
}

Piia Lavikainen 1* (D) Emma Aarnio ${ }^{1}$, Kari Jalkanen', Hilkka Tirkkonen², Päivi Rautiainen², Tiina Laatikainen ${ }^{2,3,4}$ and Janne Martikainen ${ }^{1}$

\begin{abstract}
Background: A new special reimbursement scheme (SRS) for non-insulin medications used for treatment of hyperglycaemia in type 2 diabetes (T2D) was implemented in Finland on January 1, 2017. The new SRS affected all community-dwelling Finnish T2D patients as all community-dwelling residents are eligible for reimbursement for prescription medications. The aim of the study was to evaluate the impact of this co-payment increase on glycaemic control among Finnish T2D patients.

Methods: Data on glycaemic control were collected with $\mathrm{HbA1c}$ measures from electronic health records from primary health care and specialized care in the North Karelia region, Finland, from patients with a confirmed T2D diagnosis in 2012 who were alive on January 1, $2017(n=8436)$. Average HbA1c levels were measured monthly 36 months before and 33 months after the policy change. Consumption of diabetes medications was measured with defined daily doses (DDDs) based on reimbursed medication purchases. Interrupted time series design analysed with segmented regression model was applied to examine the effect of the policy change on average HbA1c levels.

Results: Eight thousand one hundred forty-three T2D patients had at least one HbA1c measurement within 01/20149/2019. Mean age of the patients was 68.1 (SD 11.3) years and 53.0\% were women. Average time since T2D diagnosis was 11.5 (SD 6.1) years. An estimated increase of 0.81 (95\% confidence interval, Cl, 0.04-1.58) $\mathrm{mmol} / \mathrm{mol}$ in average $\mathrm{HbA1c}$ levels was detected at the time of the policy change. In subgroup analyses, strongest effects were detected among patients who used only other diabetes medications than insulin or metformin in $2016(3.56 \mathrm{mmol} / \mathrm{mol}, 95 \% \mathrm{Cl}$ 2.50-4.62). Meanwhile, yearly consumption of diabetes medications decreased slightly from 618.9 (SD 487.8) DDDs/ patient in 2016 to 602.9 (SD 475.6) DDDs/patient in 2017 ( $p=0.048$ ).

(Continued on next page)
\end{abstract}

\footnotetext{
* Correspondence: piia.lavikainen@uef.fi

${ }^{1}$ Faculty of Health Sciences, School of Pharmacy, University of Eastern Finland, P.O.Box. 1627, FI-70211 Kuopio, Finland

Full list of author information is available at the end of the article
}

C C The Author(s). 2020 Open Access This article is licensed under a Creative Commons Attribution 4.0 International License, which permits use, sharing, adaptation, distribution and reproduction in any medium or format, as long as you give appropriate credit to the original author(s) and the source, provide a link to the Creative Commons licence, and indicate if changes were made. The images or other third party material in this article are included in the article's Creative Commons licence, unless indicated otherwise in a credit line to the material. If material is not included in the article's Creative Commons licence and your intended use is not permitted by statutory regulation or exceeds the permitted use, you will need to obtain permission directly from the copyright holder. To view a copy of this licence, visit http://creativecommons.org/licenses/by/4.0/ The Creative Commons Public Domain Dedication waiver (http://creativecommons.org/publicdomain/zero/1.0/) applies to the data made available in this article, unless otherwise stated in a credit line to the data. 


\begin{abstract}
(Continued from previous page)
Conclusions: Simultaneously with the increase of the co-payment level, the average HbA1c level increased among T2D patients from the North Karelia region, Finland. This may be explained by the decreased consumption of diabetes medications between 2016 and 2017. Special attention should be allocated to glycaemic control of patients utilizing only other antidiabetic medications than metformin or insulin.
\end{abstract}

Keywords: Type 2 diabetes, Co-payment increase, Glycaemic control

\section{Background}

Type 2 diabetes (T2D) is a widespread disease with rapidly increasing prevalence. In Finland alone, the current prevalence of T2D is around $8 \%$ and the disease is causing around 15\% of the total expenditures of the Finnish health care system [1,2]. When compared with other Nordic countries, consumption of diabetes medications is high in Finland [3] causing high pharmaceutical expenditure. For this, a new special reimbursement scheme (SRS) for noninsulin medications used for treatment of hyperglycaemia in T2D was implemented in Finland on January 1, 2017 [46]. The new SRS affected all community-dwelling Finnish T2D patients utilizing any other diabetes medication than insulin because in Finland, all community-dwelling residents are eligible for reimbursement for prescription medications. During the first year of the new legislation coming into effect, the medication reimbursement costs lowered by 24\% (EUR 26 million), but simultaneously the co-payments of T2D patients more than tripled (from EUR 11.9 million to EUR 39.7 million, + 334\%) [7].

In previous studies, co-payment increase related to diabetes medications is reported to be associated with decreased use of $[8,9]$ and lower adherence to medications [10-16], and therefore, with reduced glycaemic control $[15,16]$. These changes may have clinical implications in terms of glycaemic control, which in turn is known to be associated with long-term micro- and macrovascular complications [17-19]. Therefore, the aim of the present study was to evaluate the impact of the co-payment increase on glycaemic control among Finnish T2D patients. To provide reasons for possible changes in glycaemic control, we also investigated changes in consumption of diabetes medications before and after the policy change.

\section{Methods \\ Setting}

The Finnish SRS and the policy change are described in detail in Lavikainen et al. (2020) and Suviranta et al. (2019) [20, 21]. Briefly, all Finnish residents are eligible for reimbursement for prescription medications purchased from community pharmacies according to three categories based on medical grounds [22] after an initial deductible of EUR 50 per calendar year (since 2015) [23]. The reimbursement is received directly at the community pharmacies. In 2014, 35\% of the medication cost in the Basic Refund Category, $65 \%$ of the cost in the Lower and $100 \%$ of the cost after a fixed co-payment in the Higher Special Refund Categories were reimbursed by the National Health Insurance Scheme [24]. If a patient's co-payments exceed a certain limit during a calendar year (varying between EUR 572.00 and EUR 612.62 during 2014-2019), the patient becomes eligible for an Additional Refund [7, 23-26]. After reaching the Additional Refund limit, the patient pays only a fixed copayment for each purchased, reimbursable medication.

Patients having a certain chronic disease, such as diabetes, and meeting medical criteria defined by the Social Insurance Institution of Finland (SII) can be entitled to a special reimbursement for medication costs. To be granted this entitlement for antidiabetic medications other than insulin by the SII, the patient must have a confirmed diabetes diagnosis based on criteria stated by the SII [20]. To receive special reimbursement for GLP-1 (glucagonlike peptide-1) analogues, in addition to confirmed diabetes, other antidiabetic medications need to be first tried and the patient must have a body mass index $\geq 30 \mathrm{~kg} / \mathrm{m}^{2}$.

The new SRS implemented on January 1, 2017 lowered the reimbursement level of non-insulin antidiabetic medications from the Higher (100\%) to the Lower Special Refund Category (65\%) to achieve savings in medication costs [4-6]. This meant a co-payment of $35 \%$ of the cost of each purchased non-insulin medication for T2D patients instead of a fixed co-payment (EUR 3.00 in 20142015, EUR 4.50 in 2016) for each purchased medication.

\section{Study design}

The regional electronic health records (EHRs) from the Joint Municipal Authority for North Karelia Social and Health Services (Siun sote) were utilized in the present study. These regional EHRs cover both primary health care and specialized care. Extracted data consisted of patients with a confirmed T2D diagnosis (based on 10th revision of International Classification of Diseases, ICD10 [27], code E11) at the end of $2012(n=10,204)$ who were alive on Jan 1, $2017(n=8436)$. Data contained information on diagnoses as well as on laboratory assays. EHR data were compiled with information on reimbursed diabetes medication purchases (such as dispensing date and Anatomical Therapeutic Chemical (ATC) classification code [28]) for the years 1995-2010 and 
2016-2017 from the Finnish Prescription Register maintained by the SII. In addition, data on entitlements to higher medication reimbursement due to diabetes before 2011 were retrieved from the Special Reimbursement Register maintained also by the SII.

\section{Outcome measures}

In Finland, care of T2D is based on Current Care Guidelines [2] and the general aim of T2D care is to give means for early screening, to prevent complications of diabetes, ensure a balanced treatment and a good life quality for diabetes patients. Typically, HbA1c is used as a measure of long-term blood sugar level reflecting average glycaemic balance over the last 2-8 weeks with values less than $53 \mathrm{mmol} / \mathrm{mol}$ (7.0\%) considered indicating good treatment balance $[2,29]$ with some exceptions for older and the most comorbid patients. According to treatment guidelines, HbA1c level should be measured regularly (every 6-12 months).

In the study data, glycaemic control was measured with glycated haemoglobin (HbA1c) with the turbidimetric inhibition immunoanalysis method (TINIA) by the Eastern Finland laboratory (ISLAB, https://www.islab.fi) which is an accredited laboratory and participates external quality surveys. Values were standardised to International Federation of Clinical Chemistry (IFCC) units. Mean HbA1c (mmol/ mol) levels were calculated for each month 36 months before and 33 months after the policy change (i.e. January, 2014 - September, 2019) that was introduced on January 1, 2017. In every one-month time-window, data on all patients having measured his/hers $\mathrm{HbA} 1 \mathrm{c}$ at that specific window were used. If a patient had more than one HbAlc measurement within a month, the latest one was selected.

Consumption of diabetes medications was estimated with defined daily doses (DDDs, [28]) based on the Prescription register data for the years 2016 and 2017.

\section{Subgroup analyses}

Patient's age and timing of T2D diagnosis were obtained from the EHRs. Timing of T2D diagnosis was ascertained with the Finnish Prescription Register data on diabetes medication purchases and the Special Reimbursement Register data on entitlements to special refund for diabetes medications maintained by the SII. T2D diagnosis date was considered to be the first occurrence of diabetes medication purchase, entitlement to special refund or T2D diagnosis in the electronic patient database. In subgroup analyses, patients were divided to those with T2D duration from 5 to less than 10 years, 10-15 years, and those with T2D duration $>15$ years at the time of policy change.

Patients were classified according to the diabetes medication purchases from the Prescription register data in 2016. The following subgroups were formed: users of metformin (ATC code A10BA02) only, users of metformin and other oral antidiabetic medications (A10BA02 + other A10B), users of only other diabetes medications than insulin or metformin (A10B excluding A10BA02 and A10A), users of insulin and oral antidiabetic medication (including metformin) (A10A + A10B), and users of insulin (A10A) only in 2016.

\section{Other variables}

Information of concordant and discordant diseases was retrieved from the EHRs and they were measured from the time period before the policy change in Dec 31, 2016. Concordant, T2D-coexisting diseases consisted of hypertension (ICD-10: I10), coronary heart disease (I20-I25), atrial fibrillation (I48), heart failure (I50, I11.0, I13.0, I13.2), peripheral arterial diseases (I70.2, I73.9), stroke (incl. SAH, I60, I61, I63, I64, but excluding I63.6), chronic kidney disease (N18, N19), neuropathies (G59, G63, G73, G99), blindness (H54), or diabetes complications (E11.2E11.8 sublevels). Discordant diseases consisted of cancers (C00-C43, C45-C97), asthma (J45, J46), gout (M10), glaucoma (H40-H42), depression (F32, F33), dementia (F00F03, G30), mental diseases (F20-F48), chronic obstructive pulmonary disease (J43-J44), rheumatoid and other arthritis (M05-M13, M32, M33, M45), osteoporosis (M80M85), neuromuscular diseases (G70-G72), or liver diseases excluding cancers (K70-K77).

\section{Statistical analyses}

Differences in baseline characteristics between patients with and without HbA1c measurements during the follow-up were examined using standardized difference that is independent of sample size [30]. Standardized mean difference values $>10 \%$ were considered to indicate meaningful differences between the patients.

Interrupted time series [31] design was applied to examine the effect of the policy change on average monthly HbA1c levels. Time periods of 30 days 36 months before and 33 months after the policy change were utilized to define a pre-policy change segment, time of the policy change, and a post- policy change segment. Interrupted time series is a strong quasiexperimental design. It was estimated with segmented linear autoregressive error models [32]. Autocorrelation between the time points was estimated utilizing a Durbin-Watson test [31]. Autocorrelation refers to the dependency of regression residuals over the measured time points. For the results of the Durbin-Watson test, $p<$ 0.05 was considered to indicate statistically significant serial autocorrelation. Autocorrelation was automatically adjusted for in the regression models when needed.

In the primary analysis, data on the total population were utilized. However, subgroup analyses were performed based on age and T2D duration at the time of the policy change as well as diabetes medication use in 
2016. Sensitivity analyses against the primary analysis were conducted ruling out time-periods of 1-6 months after policy change (January-June, 2017) to examine the impact of potential lag time on the effect of diabetes medications on HbA1c levels. In addition, in the second sensitivity analysis, two-month time periods instead of one-month periods were applied to stabilize the potential variation due to short time-windows and to increase sample sizes within time-windows. All the analyses were conducted with SAS version 9.4 (SAS Institute Inc., Cary, North Carolina, USA).

\section{Ethics statement}

Use of the data was approved by the Ethics Committee of the Northern Savonia Hospital District (diary number $81 / 2012$ ). The study protocol was also approved by the register administrator, the Joint Municipal Authority for North Karelia Social and Health Services (Siun sote). A separate permission to link data on medication purchases and entitlements to special reimbursements was achieved from the SII (diary number 110/522/2018). Only register-based data were utilized and thus, consent from the patients was not needed.

\section{Results}

Patients with at least one HbA1c measurement during $1 / 2014-9 / 2019(n=8143)$ were on average 68.1 years (SD 11.3) old at the baseline and $53.0 \%$ were female (Table 1). A bit over two thirds (69.2\%) were on good glycaemic control (i.e. HbA1c less than $53 \mathrm{mmol} / \mathrm{mol}$ ) at the time of the policy change. Roughly a third (35.4\%) of patients had concordant diseases only in addition to T2D and $9.7 \%$ discordant diseases only, whereas $24.6 \%$ had both concordant and discordant diseases and 30.3\% had neither of them. Most patients used only metformin in 2016, followed by users of insulin and oral antidiabetic medication. Patients without HbA1c measurements ( $n=293$ or $3.5 \%$ ) during the time period were on average healthier (no concordant or discordant diseases), but, however, more of them died during the follow-up when compared to patients with HbA1c measurements $(7.9 \%$ vs. 5.8\%, respectively, see Additional file 1).

In the primary analysis, for the total population, the average HbA1c level was 52.4 (95\% confidence interval, CI, 51.9-52.9) $\mathrm{mmol} / \mathrm{mol}$ at the baseline on January, 2014 and HbA1c level increased by $0.07 \mathrm{mmol} / \mathrm{mol}$ (95\% CI $0.04-$ 0.09) per month until December 2016 (Fig. 1, Table 2). An estimated average increase of 0.81 (95\% CI 0.04-1.58) $\mathrm{mmol} / \mathrm{mol}$ was detected in HbA1c levels at the time of policy change on January, 2017. Thereafter, the average HbA1c level remained stable until September 2019.

In subgroup analyses, stronger point estimates for immediate changes in $\mathrm{HbA} 1 \mathrm{c}$ levels at the time of the policy change than in the primary analysis were detected among patients utilizing only other diabetes medications than insulin or metformin in $2016(3.56 \mathrm{mmol} / \mathrm{mol}, 95 \%$ CI 2.50-4.62) (Table 2). In addition, stronger point estimates for immediate changes in $\mathrm{HbA1c}$ levels at the time of the policy change were also detected among patients aged $\geq 75$ years (Table 2 ).

In sensitivity analyses, ruling out time-periods of 1 to 6 months (January-June, 2017) after the policy change diluted the effect of the policy change to statistically nonsignificant except in the analysis excluding the period from January to May (Table 3). Neither using two-month instead of one-month time-windows nor restricting the population to those who survived until October 2019 altered the results from the primary analysis (Table 3 ).

In total, consumption of diabetes medications decreased from 11,619 daily DDDs in 2016 to 11,446 daily DDDs in 2017 among those who were alive on Jan 1, 2018 (Table 4). Meanwhile, the number of purchases increased from 52,050 purchases in 2016 to 56,764 purchases in 2017 and the number of users decreased from 6793 patients in 2016 to 6780 patients in 2017. Number of purchases increased from an average 7.7 (SD 7.4) purchases per patient in 2016 to an average 8.4 (SD 8.2) purchases per patient in $2017(p<0.001)$. Consumption of diabetes medications per patient per purchase decreased from 81.5 (SD 60.9) DDDs/patient/purchase in 2016 to 73.6 (SD 59.3) DDDs/patient/purchase in 2017 $(p<0.001)$. Even the total consumption of medications calculated as DDDs decreased, the total yearly consumption of diabetes medications per patient who had purchases did not change between 2016 and 2017. In total, consumption of SGLT2 (sodium/glucose cotransporter 2) inhibitors increased heavily from 144,018 DDDs in 2016 to 245,228 DDDs in 2017 whereas consumption of other diabetes medications decreased during the same period (Additional file 2).

Of those utilizing only other diabetes medications than insulin or metformin in 2016 and surviving until Jan 1, $2018(n=726)$, 6.8\% started using metformin and 5.9\% insulin in addition to other diabetes medications than insulin or metformin in 2017 (Table 5).

\section{Discussion}

A small $0.8 \mathrm{mmol} / \mathrm{mol}(\sim 0.08 \%)$ immediate increase in average HbA1c levels during the first month after the new SRS was detected in glycaemic control among T2D patients from the North Karelia region, Finland. However, the largest immediate increase $(3.56 \mathrm{mmol} / \mathrm{mol}$, 95\% CI $2.50-4.62$, or $0.33 \%$ ) was observed among patients utilizing only other diabetes medications than insulin or metformin in 2016. Patients were observed to purchase smaller packages and more frequently after the policy change than before it. 


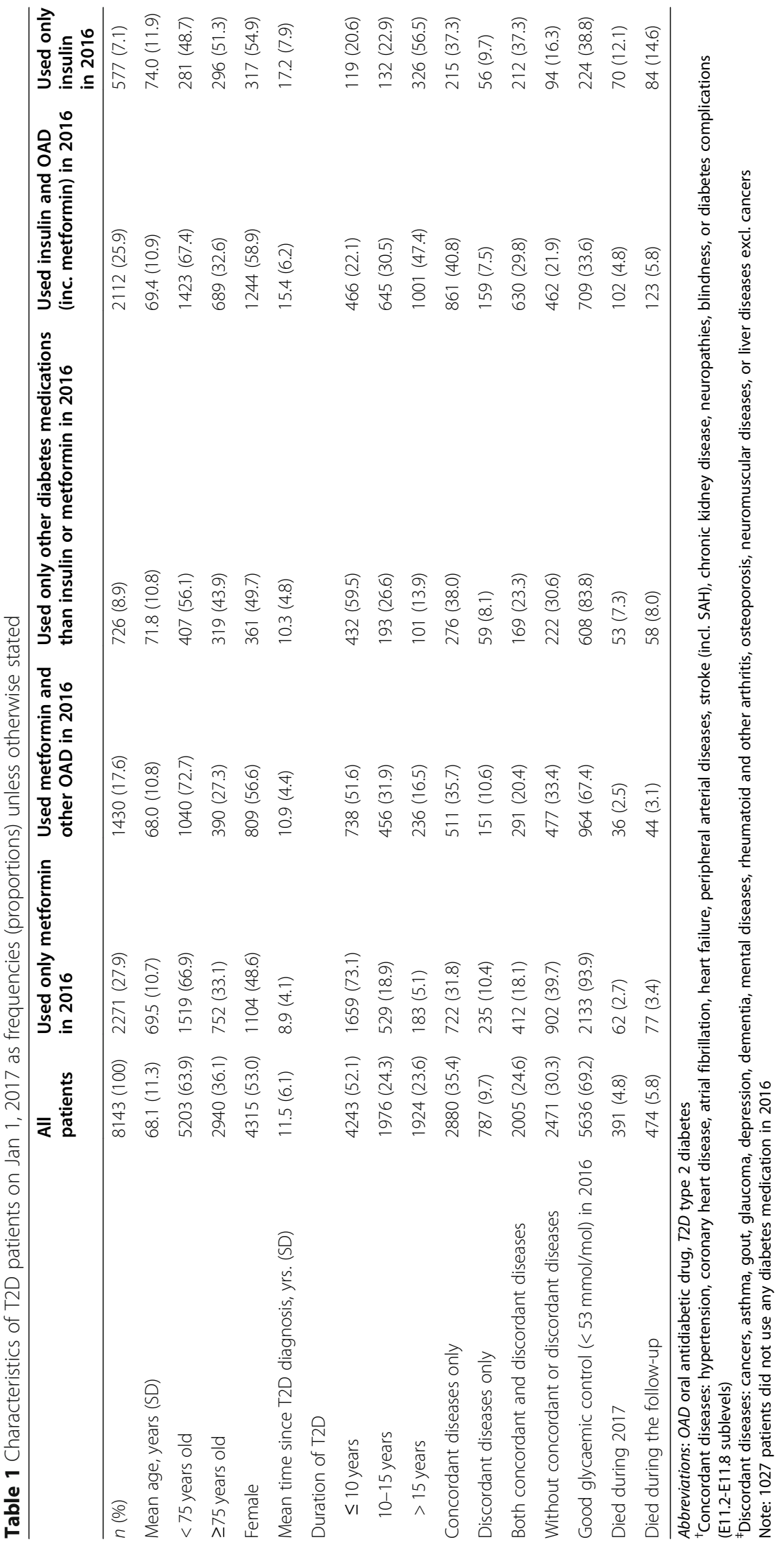




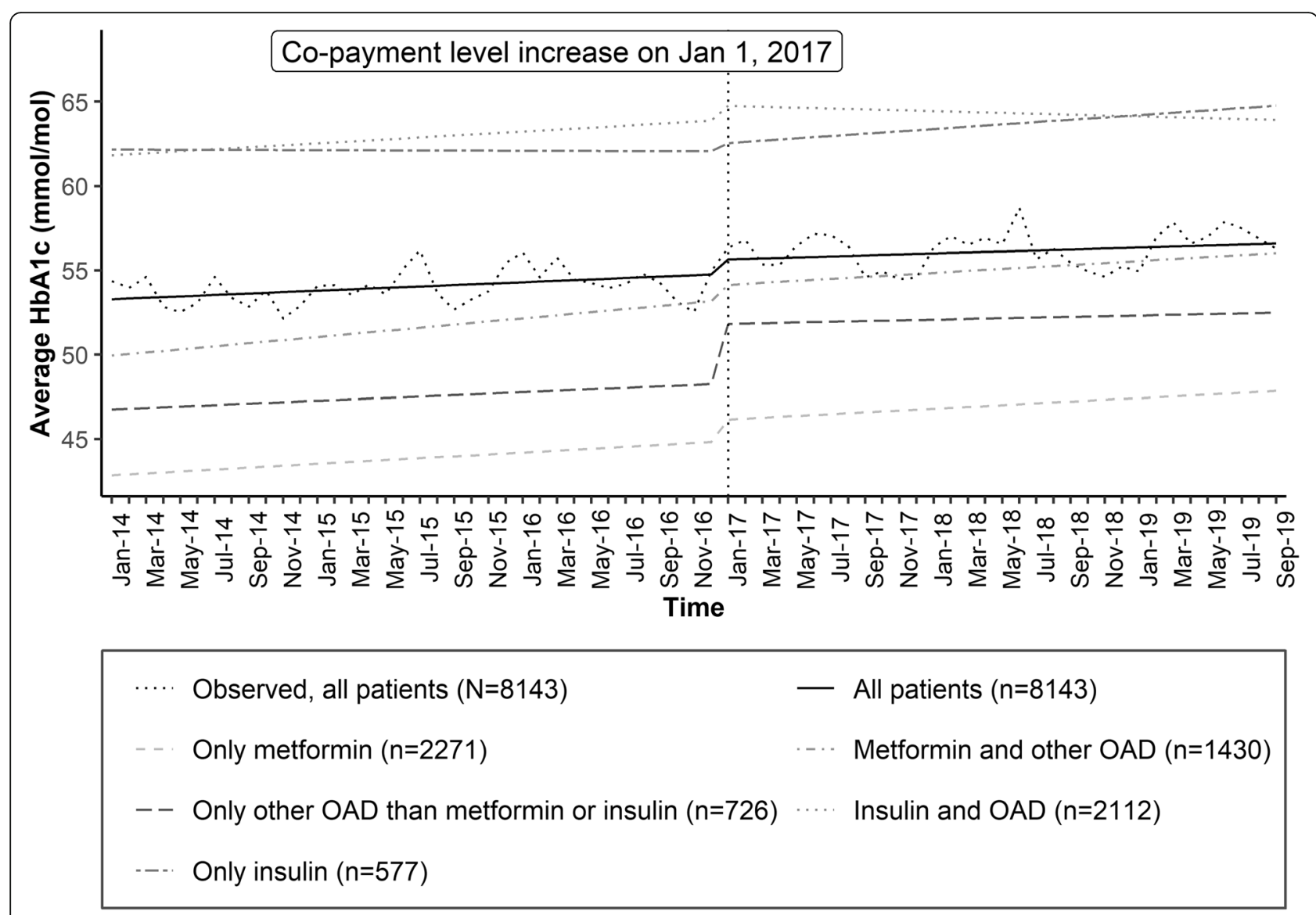

Fig. 1 Observed time series of average glycaemic control for all patients by month. Estimated trend lines show predicted values from the segmented regression analysis for all patients and by drug groupings

The estimated yearly increase of $0.84 \mathrm{mmol} / \mathrm{mol}$ $(12 \% 0.07 \mathrm{mmol} / \mathrm{mol}, 0.08 \%$ units) in average HbA1c levels observed in this study until the policy change at the beginning of 2017 is a bit over the magnitude of the estimated increase of $0.75 \mathrm{mmol} / \mathrm{mol}(0.07 \%$ units in $\mathrm{HbAlc})$ per year that was observed in our previous study among the same population in 2011-2016 [33]. The small differences in results are due to differences in densities of follow-up (monthly level in the current study vs. yearly level in the paper by Nazu et al. (2019)) in addition to differences in lengths of follow-up [33]. In the current study, an additional, immediate increase of $0.81 \mathrm{mmol} / \mathrm{mol}(0.08 \%)$ was detected at the time of the policy change in the current study. Thereafter, HbA1c values continued to increase $0.36 \mathrm{mmol} / \mathrm{mol}(0.03 \%)$ per year. Compared with other international publications on changes in treatment balance over time, rates of $1.4-1.5 \mathrm{mmol} / \mathrm{mol}(0.12-0.14 \%$ units in HbA1c) of increase per year are reported [34, 35]. The lower rate of increase in our studies may reflect the early detection and active treatment of T2D patients in the North Karelia region [36]. In addition, SGLT2 inhibitors became reimbursable in 2016 and the price of newer medications, such as GLP-1 analogues, has decreased over the study period increasing their use and, thus, reducing the use of insulins.

The new SRS has already been reported to effect patient's medication use, cause financial difficulties to purchase diabetes medications, and worsen patient's satisfaction to diabetes care [20,21]. In our study, almost $13 \%$ of the patients utilizing only other medications than insulin or metformin in 2016 started using metformin or insulin in addition to other diabetes medications in 2017. In our previous study, $28 \%$ of patients with T2D reported they discontinued non-insulin diabetes medication use due to financial reasons and $8 \%$ had initiated insulin use due to the same reasons within the first 11 months after the implementation of the new SRS [20]. In another study, we also observed that almost half (47\%) of the study participants reported some kind of an effect of the copayment level increase on their life in an open-ended question 11 months after the new SRS coming into effect [21]. Most commonly reported effects were economic effects (33\%), such as increased expenditure (17\%) or difficulty in purchasing medicines (9\%), after the co-payment level increased. However, only $2 \%$ reported they had discontinued diabetes medication use. 
Table 2 Parameter estimates (95\% confidence intervals) for average HbA1c (mmol/mol) levels over the follow-up

\begin{tabular}{|c|c|c|c|c|}
\hline & $\begin{array}{l}\text { Baseline level } \\
\text { at } 01 / 2014\end{array}$ & $\begin{array}{l}\text { Pre-policy change } \\
\text { trend in } 01 / 2014-12 / \\
2016\end{array}$ & $\begin{array}{l}\text { Change in level at the } \\
\text { time of the policy } \\
\text { change in } 01 / 2017\end{array}$ & $\begin{array}{l}\text { Post-policy change } \\
\text { trend in 02/2017-9/ } \\
2019\end{array}$ \\
\hline All patients $(n=8143)$ & 52.40 (51.88 to 52.91$)$ & 0.07 (0.04 to 0.09) & 0.81 (0.04 to 1.58$)$ & $0.03(-0.03$ to 0.08$)$ \\
\hline \multicolumn{5}{|l|}{ Subgroup analyses: } \\
\hline Patients aged $<75$ years $(n=5203)$ & 52.05 (51.50 to 52.60$)$ & 0.06 (0.04 to 0.09) & $0.79(-0.04$ to 1.62$)$ & $0.04(-0.02$ to 0.10$)$ \\
\hline Patients aged $\geq 75$ years $(n=2940)$ & 53.39 (52.59 to 54.19$)$ & $0.06(0.02$ to 0.10$)$ & 1.53 (0.40 to 2.66) & $0.00(-0.08$ to 0.09$)$ \\
\hline$\leq 10$ years duration of T2D $(n=4243)$ & 47.35 (46.80 to 47.90$)$ & 0.06 (0.04 to 0.09$)$ & $0.68(-0.03$ to 1.39$)$ & $0.05(-0.01$ to 0.11$)$ \\
\hline $\begin{array}{l}>10-15 \text { years duration of T2D } \\
(n=1976)\end{array}$ & 53.15 (52.41 to 53.89$)$ & 0.09 (0.06 to 0.13$)$ & $0.85(-0.29$ to 1.99$)$ & $0.02(-0.06$ to 0.09$)$ \\
\hline$>15$ years duration of T2D $(n=1924)$ & 59.76 (58.57 to 60.95$)$ & $0.03(-0.02$ to 0.09$)$ & $1.49(-0.11$ to 3.09$)$ & $0.02(-0.11$ to 0.15$)$ \\
\hline Used only metformin in $2016(n=2271)$ & 42.79 (42.44 to 43.14$)$ & 0.06 (0.04 to 0.07$)$ & 1.28 (0.83 to 1.73$)$ & 0.05 (0.02 to 0.09$)$ \\
\hline Used metformin and other OAD in $2016(n=1430)$ & 49.85 (49.17 to 50.53$)$ & 0.09 (0.06 to 0.12$)$ & $0.92(-0.10$ to 1.94$)$ & $0.06(-0.01$ to 0.13$)$ \\
\hline $\begin{array}{l}\text { Used only other diabetes medications than } \\
\text { insulin or metformin in } 2016(n=726)\end{array}$ & 46.71 (45.99 to 47.43$)$ & 0.04 (0.01 to 0.08) & $3.56(2.50$ to 4.62$)$ & $0.02(-0.06$ to 0.10$)$ \\
\hline $\begin{array}{l}\text { Used insulin and OAD (incl. metformin) in } \\
2016(n=2112)\end{array}$ & $61.78(60.88$ to 62.68$)$ & 0.06 (0.02 to 0.10$)$ & $0.92(-0.39$ to 2.22$)$ & $-0.03(-0.12$ to 0.07$)$ \\
\hline Used only insulin in $2016(n=577)$ & 62.18 (60.98 to 63.38$)$ & $-0.00(-0.06$ to 0.05$)$ & $0.42(-1.28$ to 2.12$)$ & $0.07(-0.06$ to 0.20$)$ \\
\hline
\end{tabular}

Abbreviations: $O A D$ oral antidiabetic drug; $T 2 D$ type 2 diabetes

The previously reported effects of the new SRS [20, 21] may show as a decline in treatment balance observed in the current study. Increases in co-payment levels are also reported to decrease adherence to diabetes medications $[15,16,37]$ which may further show as a decline in treatment balance [15]. In addition, the observed results of elevated $\mathrm{HbA1c}$ levels at the time of the policy change may be explained by the decreased consumption of diabetes medications between 2016 and 2017. We observed that the number of purchases increased while the number of users decreased due to mortality indicating that the patients purchased smaller packages and more frequently after the policy change than before it. Similar findings were observed at the national level: the consumption of diabetes medications decreased by 1\% between August, 2016 and August, 2017 although the number of users increased by $3 \%$ [38]. However, the decreasing trend in consumption of diabetes medications observed in both studies may be explained by stockpiling at the end of 2016; patients anticipated the upcoming higher prices and utilized the benefits of possibly reaching the Additional Refund limit. In another previous national level study, the annual co-payment increase was estimated to be EUR 157 on average among those utilizing DPP-4 (dipeptidyl peptidase 4) inhibitors or GLP-1 analogues, while corresponding figure for patients using older antidiabetic medicines (e.g., metformin and sulfonylureas) was EUR 12 [39]. This may be the reason why the largest immediate effects of the new SRS were seen among

Table 3 Parameter estimates (95\% confidence intervals) from sensitivity analyses for average HbA1c (mmol/mol) levels over the follow-up

\begin{tabular}{|c|c|c|c|c|}
\hline & $\begin{array}{l}\text { Baseline level } \\
\text { at } 01 / 2015\end{array}$ & $\begin{array}{l}\text { Pre-policy change } \\
\text { trend in 01/2014-12/ } \\
2016\end{array}$ & $\begin{array}{l}\text { Change in level at the } \\
\text { time of the policy } \\
\text { change in } 01 / 2017\end{array}$ & $\begin{array}{l}\text { Post-policy change } \\
\text { trend in 02/2017- } \\
9 / 2019\end{array}$ \\
\hline Primary result & $52.40(51.88$ to 52.91$)$ & 0.07 (0.04 to 0.09) & 0.81 (0.04 to 1.58$)$ & $0.03(-0.03$ to 0.08$)$ \\
\hline \multicolumn{5}{|l|}{ Results from sensitivity analyses when... } \\
\hline ...excluding 01/2017 & $52.52(51.50$ to 53.54$)$ & 0.06 (0.02 to 0.10$)$ & $1.00(-0.01$ to 2.01$)$ & $0.03(-0.07$ to 0.13$)$ \\
\hline ...excluding 01-02/2017 & 52.44 (51.89 to 53.00$)$ & 0.06 (0.04 to 0.09) & $0.72(-0.13$ to 1.57$)$ & $0.04(-0.02$ to 0.10$)$ \\
\hline ...excluding 01-03/2017 & 52.81 (51.79 to 53.23$)$ & 0.06 (0.03 to 0.10$)$ & $0.76(-0.31$ to 1.83$)$ & $0.04(-0.04$ to 0.12$)$ \\
\hline ...excluding 01-04/2017 & $52.55(51.82$ to 53.28$)$ & 0.06 (0.02 to 0.09) & $0.99(-0.10$ to 2.07$)$ & $0.04(-0.05$ to 0.12$)$ \\
\hline ...excluding 01-05/2017 & 52.59 (51.53 to 53.66$)$ & 0.05 (0.01 to 0.10$)$ & $1.28(0.14$ to 2.41$)$ & $0.03(-0.08$ to 0.15$)$ \\
\hline ...excluding 01-06/2017 & $52.76(51.73$ to 53.80$)$ & 0.04 (0.00 to 0.09) & $1.37(-0.05$ to 2.79$)$ & $0.04(-0.09$ to 0.16$)$ \\
\hline ...applying 2-month time windows & 53.04 (52.64 to 53.44$)$ & 0.09 (0.05 to 0.12) & 0.86 (0.28 to 1.44$)$ & $0.06(-0.01$ to 0.12$)$ \\
\hline $\begin{array}{l}. . . \text { restricting the population to those } \\
\text { who survived until Oct } 1,2019(n=7669)\end{array}$ & $51.95(51.46$ to 52.45$)$ & 0.07 (0.05 to 0.10$)$ & $1.00(0.25$ to 1.75$)$ & $0.03(-0.02$ to 0.09$)$ \\
\hline
\end{tabular}


Table 4 Consumption of diabetes medications in 2016 and 2017.

\begin{tabular}{|c|c|c|c|c|c|c|c|c|c|c|c|c|c|}
\hline & \multicolumn{2}{|c|}{$\begin{array}{l}N \text { of users ( } N \\
\text { of purchases) }\end{array}$} & \multicolumn{2}{|c|}{$\begin{array}{l}\text { Total consumption, } \\
\text { DDDs }\end{array}$} & \multicolumn{3}{|c|}{$\begin{array}{l}\text { Purchases/patient } \\
\text { (SD) }\end{array}$} & \multicolumn{3}{|c|}{$\begin{array}{l}\text { DDDs/patient/ } \\
\text { purchase (SD) }\end{array}$} & \multicolumn{3}{|c|}{$\begin{array}{l}\text { DDDs/patient/ } \\
\text { year (SD) }\end{array}$} \\
\hline & 2016 & 2017 & 2016 & 2017 & 2016 & 2017 & $\begin{array}{l}P \\
\text { value }\end{array}$ & 2016 & 2017 & $\begin{array}{l}P \\
\text { value }\end{array}$ & 2016 & 2017 & $\begin{array}{l}P \\
\text { value }\end{array}$ \\
\hline All patients $(n=8143)$ & $\begin{array}{l}7116 \\
(55,104)\end{array}$ & $\begin{array}{l}7036 \\
(58,212)\end{array}$ & 12,065 & 11,621 & $\begin{array}{l}7.7 \\
(7.5)\end{array}$ & $\begin{array}{l}8.3 \\
(8.2)\end{array}$ & $\begin{array}{l}< \\
0.001\end{array}$ & $\begin{array}{l}79.9 \\
(61.3)\end{array}$ & $\begin{array}{l}72.9 \\
(59.4)\end{array}$ & $\begin{array}{l}< \\
0.001\end{array}$ & $\begin{array}{l}618.9 \\
(487.8)\end{array}$ & $\begin{array}{l}602.9 \\
(475.6)\end{array}$ & 0.048 \\
\hline $\begin{array}{l}\text { Patients alive on Jan 1, } 2018 \\
(n=8025)\end{array}$ & $\begin{array}{l}6793 \\
(52,050)\end{array}$ & $\begin{array}{l}6780 \\
(56,764)\end{array}$ & 11,619 & 11,446 & $\begin{array}{l}7.7 \\
(7.4)\end{array}$ & $\begin{array}{l}8.4 \\
(8.2)\end{array}$ & $\begin{array}{l}< \\
0.001\end{array}$ & $\begin{array}{l}81.5 \\
(60.9)\end{array}$ & $\begin{array}{l}73.6 \\
(59.3)\end{array}$ & $\begin{array}{l}< \\
0.001\end{array}$ & $\begin{array}{l}624.3 \\
(489.0)\end{array}$ & $\begin{array}{l}616.2 \\
(477.2)\end{array}$ & 0.326 \\
\hline \multicolumn{14}{|l|}{ Subgroup analyses: } \\
\hline $\begin{array}{l}\text { Used only metformin in } \\
2016(n=2271)\end{array}$ & $\begin{array}{l}2271 \\
(9632)\end{array}$ & $\begin{array}{l}2184 \\
(10,036)\end{array}$ & 1678 & 1681 & $\begin{array}{l}4.2 \\
(4.2)\end{array}$ & $\begin{array}{l}4.6 \\
(4.6)\end{array}$ & 0.007 & $\begin{array}{l}63.6 \\
(42.6)\end{array}$ & $\begin{array}{l}61.1 \\
(42.2)\end{array}$ & $\begin{array}{l}< \\
0.001\end{array}$ & $\begin{array}{l}269.6 \\
(129.0)\end{array}$ & $\begin{array}{l}280.9 \\
(145.4)\end{array}$ & 0.006 \\
\hline $\begin{array}{l}\text { Used metformin and other } \\
\text { OAD in } 2016(n=1430)\end{array}$ & $\begin{array}{l}1430 \\
(12,946)\end{array}$ & $\begin{array}{l}1412 \\
(14,009)\end{array}$ & 2806 & 2700 & $\begin{array}{l}9.1 \\
(7.7)\end{array}$ & $\begin{array}{l}9.9 \\
(8.7)\end{array}$ & 0.005 & $\begin{array}{l}79.1 \\
(44.0)\end{array}$ & $\begin{array}{l}70.3 \\
(44.9)\end{array}$ & $\begin{array}{l}< \\
0.001\end{array}$ & $\begin{array}{l}716.3 \\
(268.6)\end{array}$ & $\begin{array}{l}697.9 \\
(299.2)\end{array}$ & 0.084 \\
\hline $\begin{array}{l}\text { Used only other diabetes } \\
\text { medications than insulin or } \\
\text { metformin in } 2016(n=726)\end{array}$ & $\begin{array}{l}726 \\
(4009)\end{array}$ & $\begin{array}{l}694 \\
(4316)\end{array}$ & 714 & 701 & $\begin{array}{l}5.5 \\
(5.3)\end{array}$ & $\begin{array}{l}6.2 \\
(5.6)\end{array}$ & 0.016 & $\begin{array}{l}65.0 \\
(41.9)\end{array}$ & $\begin{array}{l}59.3 \\
(39.7)\end{array}$ & $\begin{array}{l}< \\
0.001\end{array}$ & $\begin{array}{l}358.8 \\
(169.4)\end{array}$ & $\begin{array}{l}368.6 \\
(193.9)\end{array}$ & 0.309 \\
\hline $\begin{array}{l}\text { Used insulin and OAD (incl. } \\
\text { metformin) in } 2016(n=2112)\end{array}$ & $\begin{array}{l}2112 \\
(25,656)\end{array}$ & $\begin{array}{l}2088 \\
(26,503)\end{array}$ & 6046 & 5745 & $\begin{array}{l}12.1 \\
(9.0)\end{array}$ & $\begin{array}{l}12.7 \\
(9.8)\end{array}$ & 0.061 & $\begin{array}{l}86.0 \\
(72.3)\end{array}$ & $\begin{array}{l}79.2 \\
(70.7)\end{array}$ & $\begin{array}{l}< \\
0.001\end{array}$ & $\begin{array}{l}1044.9 \\
(572.1)\end{array}$ & $\begin{array}{l}1004.9 \\
(559.7)\end{array}$ & 0.022 \\
\hline $\begin{array}{l}\text { Used only insulin in } 2016 \\
(n=577)\end{array}$ & $\begin{array}{l}577 \\
(2861)\end{array}$ & $\begin{array}{l}548 \\
(2893)\end{array}$ & 821 & 737 & $\begin{array}{l}5.0 \\
(2.5)\end{array}$ & $\begin{array}{l}5.3 \\
(3.2)\end{array}$ & 0.064 & $\begin{array}{l}104.8 \\
(77.0)\end{array}$ & $\begin{array}{l}93.0 \\
(70.4)\end{array}$ & $\begin{array}{l}< \\
0.001\end{array}$ & $\begin{array}{l}519.6 \\
(440.6)\end{array}$ & $\begin{array}{l}490.8 \\
(413.1)\end{array}$ & 0.259 \\
\hline $\begin{array}{l}\text { Patients alive on Oct 1, } 2019 \\
(n=7669)\end{array}$ & $\begin{array}{l}6730 \\
(51,486)\end{array}$ & $\begin{array}{l}6721 \\
(56,235)\end{array}$ & 11,526 & 11,372 & $\begin{array}{l}7.7 \\
(7.3)\end{array}$ & $\begin{array}{l}8.4 \\
(8.2)\end{array}$ & $\begin{array}{l}< \\
0.001\end{array}$ & $\begin{array}{l}81.7 \\
(60.7)\end{array}$ & $\begin{array}{l}73.8 \\
(59.3)\end{array}$ & $\begin{array}{l}< \\
0.001\end{array}$ & $\begin{array}{l}625.1 \\
(488.6)\end{array}$ & $\begin{array}{l}617.6 \\
(477.9)\end{array}$ & 0.366 \\
\hline
\end{tabular}

Abbreviations: $D D D$ defined daily dose, $O A D$ oral antidiabetic drug

patients utilizing only other diabetes medications than insulin or metformin in 2016 in this study. To remind, insulins remained in the Higher Special Refund Category $(100 \%)$ at the time of the policy change. Furthermore, increasing prices may delay initiation of diabetes medications other than insulin or metformin. Further examination on use of these medications is needed among new T2D patients with a longer follow-up.

Strengths of our study are inclusion of all patients with a diagnosed T2D in 2012 in the North Karelia region and application of data on all available HbA1c measurements, and, thus, avoiding selection bias. In addition, all the municipalities of the North Karelia use the same regional laboratory and the same standardized methods for HbA1c testing. Utilization of register-based data allows us to avoid recall bias, too.

However, our study also includes some weaknesses. At the same time of the introduction of the new SRS, the Joint Municipal Authority for North Karelia Social and Health Services (Siun sote) was launched in the North Karelia region, Eastern Finland. Siun sote is a consortium of municipalities and organizes health care services for 14 municipalities in North Karelia instead of each municipality arranging its own services. However, how introduction of new structure for organizing health care services could affect T2D patients and their glycaemic

Table 5 Changes in medication use between 2016 and 2017 by medication subgroups among those who survived until Jan 1, 2018 $(n=8025)$

\begin{tabular}{|c|c|c|c|c|c|c|}
\hline & $\begin{array}{l}\text { Used only } \\
\text { metformin } \\
\text { in } 2017\end{array}$ & $\begin{array}{l}\text { Used metformin } \\
\text { and other OAD } \\
\text { in } 2017\end{array}$ & $\begin{array}{l}\text { Used only other } \\
\text { diabetes medications } \\
\text { than insulin or } \\
\text { metformin in } 2017\end{array}$ & $\begin{array}{l}\text { Used insulin and } \\
\text { OAD (incl. metformin) } \\
\text { in } 2017\end{array}$ & $\begin{array}{l}\text { Used only } \\
\text { insulin in } \\
2017\end{array}$ & $\begin{array}{l}\text { Did not use } \\
\text { antidiabetic } \\
\text { medications in } \\
2017\end{array}$ \\
\hline $\begin{array}{l}\text { Used only metformin in } \\
2016(n=2271)\end{array}$ & 1967 (89.0) & $147(6.7)$ & $10(0.5)$ & $16(0.7)$ & $1(0.1)$ & $68(3.1)$ \\
\hline $\begin{array}{l}\text { Used metformin and other } \\
\text { OAD in } 2016(n=1430)\end{array}$ & $42(3.0)$ & 1164 (83.5) & $76(5.5)$ & $101(7.3)$ & $3(0.2)$ & $8(0.6)$ \\
\hline $\begin{array}{l}\text { Used only other diabetes } \\
\text { medications than insulin or } \\
\text { metformin in } 2016(n=726)\end{array}$ & $2(0.3)$ & $46(6.8)$ & $563(83.7)$ & $40(5.9)$ & 0 & $22(3.3)$ \\
\hline $\begin{array}{l}\text { Used insulin and OAD (incl. } \\
\text { metformin) in } 2016 \text { ( } n=2112)\end{array}$ & $11(0.6)$ & $23(1.1)$ & $17(0.9)$ & 1889 (94.0) & $63(3.1)$ & $7(0.4)$ \\
\hline Used only insulin in $2016(n=577)$ & 0 & 0 & $1(0.2)$ & $35(6.9)$ & $461(90.9)$ & $10(2.0)$ \\
\hline
\end{tabular}


control, remains unknown. To our knowledge, treatment routines remained similar as before the introduction of the consortium. Still, we were not able to separate the effect of the new SRS of that of the new service structure. It should be noted that all the patients included in our study were diagnosed with T2D at least 1 year before the start of the follow-up of HbA1c development and at least 4 years before the policy change in Jan, 2017. In addition, according to our previous study, younger patients with T2D were poorly monitored compared with the older patients in the North Karelia region [33]. Furthermore, we did not have information on patients using private health care services. However, as persons utilizing private health care services are not likely to use only private health care services in the care of T2D due to, for example, economic issues, this is not a big concern.

\section{Conclusions}

T2D is a lifelong, progressing disease that, among others, affects quality of life, introduces comorbidities and increases mortality risk [2]. Higher HbA1c levels (> 53 $\mathrm{mmol} / \mathrm{mol}$ or $7.0 \%$ ) in turn are reported to increase the risk of micro- and macrovascular complications [17-19]. We observed that the co-payment level increase of antidiabetic medications had the strongest, immediate average effect on glycaemic control among those who were utilizing only other diabetes medications than insulin or metformin at the time of the policy change. The observed $\mathrm{HbA} 1 \mathrm{c}$ increase of $3.56 \mathrm{mmol} / \mathrm{mol}(0.33 \%)$ at the time of the policy change equals over $17 \%$ increase in the risk of microvascular complications, almost 5\% increase in the risk of myocardial infarctions and 9\% increase in the risk of diabetes related deaths according to the risk models from the UKPDS study [40]. Therefore, future studies are warranted to monitor long-term incidence of complications as well as related health and economic outcomes as an outcome of this policy change in this specific subgroup of patients.

\section{Supplementary Information}

The online version contains supplementary material available at https://doi. org/10.1186/s12913-020-05952-6.

Additional file 1. Characteristics of T2D patients at the time of the copayment increase on Jan 1, 2017 as frequencies (proportions) unless otherwise stated.

Additional file 2. Number of purchases and total DDDs by ATC subgroups in 2016 and 2017.

\section{Abbreviations}

ATC: Anatomical Therapeutic Chemical; Cl: Confidence interval; DDD: Defined daily dose; DPP-4: Inhibitors of dipeptidyl peptidase 4; EHRs: Electronic health records; GLP-1: Glucagon-like peptide-1; ICD-10: 10th revision of International Classification of Diseases; SGLT2: Sodium/glucose cotransporter 2; SII: The Social Insurance Institute of Finland; SRS: Special reimbursement scheme; T2D: Type 2 diabetes

\section{Acknowledgements}

This study has been presented as a poster at the ISPOR Europe 2019 in Copenhagen, Denmark in November 2019 (Lavikainen P, Aarnio E, Jalkanen K, Tirkkonen H, Rautiainen P, Laatikainen T, Martikainen J. PDB76 - Impact of copayment increase of antidiabetic medications on glycaemic control in Finnish patients with type 2 diabetes. Value in Health 2019;22(S3):S586-S587. DOI: https://doi.org/10.1016/j.jval.2019.09.958).

\section{Authors' contributions}

$\mathrm{PL}, \mathrm{EA}, \mathrm{KJ}, \mathrm{TL}$, and JM planned the study. TL acquired the data. PL preprocessed the data, performed statistical analyses, and drafted the first version of the manuscript. PL had full access to all the data in the study and takes responsibility for the integrity of the data and the accuracy of the data analyses. PL, EA, KJ, HT, PR, TL, and JM contributed to the interpretation of the data, revised the manuscript, and approved the final manuscript. The authors read and approved the final manuscript.

\section{Funding}

This study was partly funded by the Social Insurance Institution of Finland (diary number 34/26/2018), Finnish Diabetes Association, the Research Committee of the Kuopio University Hospital Catchment Area for the State Research Funding (project QCARE, Joensuu, Finland), the Strategic Research Council at the Academy of Finland (project IMPRO, 312703).

The funders had no role in the design of the study and collection, analysis, and interpretation of data and in writing the manuscript.

\section{Availability of data and materials}

Due to individual privacy law, data sharing is not possible and are not publicly available. An anonymised version of the data is available upon reasonable request from the corresponding author with appropriate permissions of the Joint Municipal Authority For North Karelia Social and Health Services (Siun sote) and the Social Insurance Institute.

\section{Ethics approval and consent to participate}

Use of the data was approved by the Ethics Committee of the Northern Savonia Hospital District (diary number 81/2012). The study protocol was also approved by the register administrator, the Joint Municipal Authority For North Karelia Social and Health Services (Siun sote). A separate permission to link data on drug purchases and special reimbursements was achieved from the Social Insurance Institute (diary number 110/522/2018). We utilized only register-based data and thus, consent from the patients was not needed.

\section{Consent for publication \\ Not applicable.}

\section{Competing interests}

$J M$ is a founding partner of ESiOR Oy and a board member of Siltana Oy. These companies were not involved in carrying out this research. PL, EA, KJ, HT, PR and TL declare no conflicts of interest.

\section{Author details \\ ${ }^{1}$ Faculty of Health Sciences, School of Pharmacy, University of Eastern

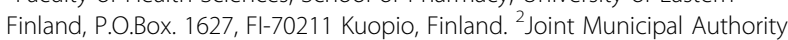 for North Karelia Social and Health Services (Siun Sote), Joensuu, Finland. ${ }^{3}$ Department of Public Health Solutions, National Institute for Health and Welfare, Helsinki, Finland. ${ }^{4}$ Institute of Public Health and Clinical Nutrition, University of Eastern Finland, Kuopio, Finland.}

Received: 28 April 2020 Accepted: 20 November 2020

Published online: 27 November 2020

\section{References}

1. Koski S. Diabetes barometer 2019 (in Finnish). The Finnish diabetes association, 2019. Available at: https:/diabetes.fi/diabetesbarometri. Accessed January 8, 2020.

2. Type 2 diabetes, Current Care Guidelines. Working group set up by the Finnish Medical Society Duodecim, the Finnish Society of Internal Medicine and the Medical Advisory Board of the Finnish Diabetes Society. Helsinki: The Finnish Medical Society Duodecim, 2018 (Referred October 26, 2018). Available online at: www.kaypahoito.fi. Accessed January 8, 2020. 
3. Health Statistics for the Nordic Countries 2017. Nordic Medico-Statistical Committee; 2017. p. 108. Available at: https:/norden.diva-portal.org/smash/ get/diva2:1148509/FULLTEXT05.pdf. Accessed 25 Nov 2020.

4. Finland, a land of solutions. Strategic Programme of Prime Minister Juha Sipilä's Government 29 May 2015. Government Publications 12/2015. Available at: https://vnk.fi/documents/10616/1095776/Ratkaisujen+Suomi_ EN.pdf/c2f3123a-d891-4451-884a-a8cb6c747ddd/Ratkaisujen+Suomi_EN.pdf. pdf?version=1.0. Accessed January 8, 2020 .

5. Finnish Government. Government proposal 184/2016 [in Finnish]. Available at: https://www.eduskunta.fi/FI/vaski/HallituksenEsitys/Documents/HE_184+2 016.pdf. Accessed 8 Jan 2020.

6. Ruskoaho $\mathrm{H}$. Inspection of the medicine reimbursement scheme regarding the savings in medicines in 2017 [in Finnish]. Reports and memos of the Ministry of Social Affairs and Health 31/2016. Available at: http://urn.fi/URN ISBN:978-952-00-3815-1. Accessed January 8, 2020.

7. Finnish medicines agency fimea and social insurance institution. Finnish Statistics on Medicines 2017. Helsinki; 2018. Available at: http://urn.fi/URN: NBN:fi-fe2018112148808. Accessed 25 Nov 2020.

8. Goldman DP, Joyce GF, Escarce JJ, Pace JE, Solomon MD, Laouri M, Lansman PB, Teutsch SM. Pharmacy benefits and the use of drugs by the chronically ill. JAMA. 2004;291:2344-50.

9. Roblin DW, Platt R, Goodman MJ, Hsu J, Nelson WW, Smith DH, Andrade SE, Soumerai SB. Effect of increased cost-sharing on oral hypoglycemic use in five managed care organizations: how much is too much? Med Care. 2005; 43:951-9.

10. Barron J, Wahl P, Fisher M, Plauschinat C. Effect of prescription copayments on adherence and treatment failure with oral antidiabetic medications. P T. 2008;33:532-53

11. Colombi AM, Yu-Isenberg K, Priest J. The effects of health plan copayments on adherence to oral diabetes medication and health resource utilization. J Occup Environ Med. 2008;50:535-41. https://doi.org/10.1097/JOM. Ob013e31816ed011.

12. Eaddy MT, Cook CL, O'Day K, Burch SP, Cantrell CR. How patient costsharing trends affect adherence and outcomes: a literature review. P T. 2012;37:45-55

13. Gu Q, Zeng F, Patel BV, Tripoli LC. Part D coverage gap and adherence to diabetes medications. Am J Manag Care. 2010;16:911-8.

14. Henk HJ, Lopez JMS, Bookhart BK. Novel type 2 diabetes medication access and effect of patient cost sharing. J Manag Care Spec Pharm. 2018;24:84755. https://doi.org/10.18553/jmcp.2018.24.9.847.

15. Hunt J, Rozenfeld Y, Shenolikar R. Effect of patient medication cost share on adherence and glycemic control. Manag Care. 2009;18:47-53.

16. Thornton Snider J, Seabury S, Lopez J, McKenzie S, Wu Y, Goldman DP. Impact of type 2 diabetes medication cost sharing on patient outcomes and health plan costs. Am J Manag Care. 2016;22:433-40.

17. Selvin E, Marinopoulos S, Berkenblit G, Rami T, Brancati FL, Powe NR, Golden SH. Meta-analysis: glycosylated hemoglobin and cardiovascular disease in diabetes mellitus. Ann Intern Med. 2004;141:421-31.

18. Stratton IM, Adler Al, Neil HA, Matthews DR, Manley SE, Cull CA, Hadden D, Turner RC, Holman RR. Association of glycaemia with macrovascular and microvascular complications of type 2 diabetes (UKPDS 35): prospective observational study. BMJ. 2000;321:405-12.

19. UKPDS Group. Intensive blood-glucose control with sulphonylureas or insulin compared with conventional treatment and risk of complications in patients with type 2 diabetes (UKPDS 33). Lancet. 1998:352:837-53.

20. Lavikainen P, Aarnio E, Mäntyranta P, Niskanen L, Martikainen J. Short-term impact of co-payment level increase on the use of medication and patientreported outcomes in Finnish patients with type 2 diabetes. Health Policy. 2020. https://doi.org/10.1016/j.healthpol.2020.08.001.

21. Suviranta T, Timonen J, Martikainen J, Aarnio E. The effects of reimbursement reform of antidiabetic medicines from the patients' perspective - a survey among patients with type 2 diabetes in Finland. BMC Health Serv Res. 2019;19:769.

22. Ministry of Social Affairs and Health. Health Insurance Act 2004/1224 (in Finnish). Available at: https://www.finlex.fi/fi/laki/ajantasa/2004/20041224. Accessed January 8, 2020.

23. Finnish Medicines Agency Fimea and Social Insurance Institution. Finnish Statistics on Medicines 2015. Helsinki; 2016. Available at: http://urn.fi/URN: NBN:fi-fe2016112829993. Accessed 25 Nov 2020.
24. Finnish Medicines Agency Fimea and Social Insurance Institution. Finnish Statistics on Medicines 2014. Helsinki; 2015. Available at: http://urn.fi/URN: NBN:fi-fe201602247346. Accessed 25 Nov 2020.

25. Finnish Medicines Agency Fimea and Social Insurance Institution. Finnish Statistics on Medicines 2016. Helsinki; 2017. Available at: http://urn.fi/URN: NBN:fi-fe2017111750773. Accessed 25 Nov 2020.

26. Finnish Medicines Agency Fimea and Social Insurance Institution. Finnish Statistics on Medicines 2018. Helsinki; 2019. Available at: http://urn.fi/URN: NBN.fi-fe2019123149481. Accessed 25 Nov 2020.

27. WHO. International Statistical Classification of Diseases and Related Health Problems 10th revision. Available at: http://apps.who.int/classifications/icd 0/browse/2010/en. Accessed October 10, 2019.

28. WHO Collaborating Centre for Drug Statistics Methodology. ATC/DDD Index 2020. Oslo; 2019. Available at: http://www.whocc.no/atc_ddd_index/. Accessed 25 Nov 2020

29. American Diabetes Association. 8. Pharmacologic Approaches to Glycemic Treatment. Diab Care 2017; 40(Suppl 1):S64-S74. DOl: https://doi.org/10. 2337/dc17-S011.

30. Austin PC. Goodness-of-fit diagnostics for the propensity score model when estimating treatment effects using covariate adjustment with the propensity score. Pharmacoepidemiol Drug Saf. 2008;17:1202-17.

31. Penfold RB, Zhang F. Use of interrupted time series analysis in evaluating health care quality improvements. Acad Pediatr. 2013;13(Suppl 6):S38-44.

32. Wagner AK, Soumerai SB, Zhang F, Ross-Degnan D. Segmented regression analysis of interrupted time series studies in medication use research. J Clin Pharm Ther. 2002:27:299-309.

33. Nazu NA, Lindström J, Rautiainen $P$, Tirkkonen $H$, Wikström $K$, Repo T, Laatikainen T. Maintenance of good glycaemic control is challenging - a cohort study of type 2 diabetes patient in North Karelia, Finland. Int I Clin Pract. 2019;73:e13313.

34. Donnelly LA, Zhou K, Doney ASF, Jennison C, Franks PW, Pearson ER. Rates of glycaemic deterioration in a real-world population with type 2 diabetes. Diabetologia. 2018:61:607-15.

35. Kahn SE, Haffner SM, Heise MA, Herman WH, Holman RR, Jones NP, et al. Glycemic durability of rosiglitazone, metformin, or glyburide monotherapy. N Engl J Med. 2006;355:2427-43.

36. Wikström K, Toivakka M, Rautianen P, Tirkkonen $H$, Repo $T$, Laatikainen $T$. Electronic health records as valuable data sources in health care quality improvement process. Health Serv Res Manag Epidemiol. 2019;6: 2333392819852879. https://doi.org/10.1177/2333392819852879.

37. Gibson TB, Song X, Alemayehu B, Wang SS, Waddell JL, Bouchard JR, Forma F. Cost sharing, adherence, and health outcomes in patients with diabetes. Am J Manag Care. 2010;16(7):589-600.

38. Kurko T, Martikainen J, Rättö H, Aaltonen K. Consumption of diabetes medications decreased to some extent in 2017 (in Finnish). Kelan Tutkimusblogi, published on March 16, 2018. Available at: https:// tutkimusblogi.kela.fi/arkisto/4466

39. Kurko T, Heino P, Martikainen JE, Aaltonen K. Use of diabetes drugs and the impact of lowering of the reimbursement rate on diabetic patients' annual copayments - a microsimulation study [in Finnish with an English abstract]. Finn Med J. 2018;73:1584-9.

40. Stratton IM, Adler Al, Neil HA, Matthews DR, Manley SE, Cull CA, Hadden D, Turner RC, Holman RR. Association of Glycaemia with Macrovascular and Microvascular Complications of type 2 diabetes (UKPDS 35): prospective observational study. BMJ. 2000:321(7258):405-12.

\section{Publisher's Note}

Springer Nature remains neutral with regard to jurisdictional claims in published maps and institutional affiliations. 